\title{
Winter cover crops to reduce herbicide inputs in maize crops
}

\author{
M.R. Trolove ${ }^{1}$, T.K. James ${ }^{1}$, A.W. Holmes ${ }^{2}$, M.D. Parker ${ }^{2}$, S.J. McDougall ${ }^{2}$ and M.R. Pirie ${ }^{1}$ \\ ${ }^{1}$ AgResearch, Ruakura Research Centre, PB 3123, Hamilton 3240, New Zealand \\ ${ }^{2}$ Foundation for Arable Research, 113C Ruakura Road, Ruakura, Hamilton 3240, \\ New Zealand \\ Corresponding author: michael.trolove@agresearch.co.nz
}

\begin{abstract}
Winter cover crops potentially have a number of positive production and environmental benefits on subsequent maize (Zea mays) crops. A field study was undertaken in 2016/17 to evaluate the effects of winter cover crop residues on the emergence and growth of weeds, required herbicide inputs, and yields of maize in comparison to a winter fallow. Weed ground cover at maize canopy closure was $81-85 \%$ less than the winter fallow in plots with ryegrass (Lolium multiflorum), oats (Avena sativa) and gland clover (Trifolium glanduliferum) residues and 57\% less in faba bean (Vicia faba). Ryegrass and oats residues maintained ground coverage of $>70 \%$, while clover had only $6 \%$ at canopy closure, but suppressed weeds similarly. In the absence of herbicides maize silage yields in plots with cover crop residues were similar to those in herbicide treatments, although maize establishment and growth was slower in oats and ryegrass.
\end{abstract}

Keywords cover crop, maize, weed control, sustainable production.

\section{INTRODUCTION}

The use of winter annual cover crops following maize production in New Zealand arable farming has increased since the 1990s, largely due to the intensification of farming systems in the country (Densley et al. 2006). Winter cover crops used for forage can increase annual farm production on average by $15 \%$ or up to $27 \%$ of total annual dry matter (DM) yield (Densley et al. 2006). They are also seen as an important tool in mitigating the adverse environmental impacts caused by intensification (Williams et al. 2010), such as reducing soil erosion and nitrogen leaching while increasing soil organic carbon and improving soil structure and water holding capacity (Foundation for Arable Research 2005).
During the last 20 years, researchers overseas have studied the effects of combining no-till (or direct drill) with cover crops as a means to reduce weed establishment within cropping fields and minimise herbicide input, while maintaining crop yields (Yenish et al. 1996; Galloway \& Weston 1996; Fisk et al. 2001; Bezuidenhout et al. 2012). These studies have demonstrated that highbiomass producing cover crops, such as annual grasses or winter cereals, inhibit weed incursion. In contrast, some legumes, particularly clovers, have a similar effect but produce lower biomass. With improved direct drilling machinery (Baker et al. 2003), more industry experience (Triplett \& Dick 2008) and improvements in soil quality 
(Pearson \& Wilson 2002), a no-till regime combined with cover cropping has potential benefits in New Zealand. Limited studies have been carried out in this country because long-term continuous mono-cropping is less common here than in other countries (Millner \& Roskruge 2013) and weed seedbanks are usually large (Rahman et al. 1996). However, there is a growing interest in minimising artificial inputs into New Zealand farming systems as increased compliance with environmental regulations is required (Millner \& Roskruge 2013) along with moves toward more sustainable production.

A preliminary field trial was undertaken during 2015/16 to assess various cover crop/herbicide combinations and refine experimental protocols but the cover crop treatments were unreplicated (M.R. Trolove unpublished data). Therefore, the objectives of this study were: to evaluate the effectiveness of different winter cover crops for weed suppression, with and without the use of both pre- and post-emergence herbicide inputs; and to determine the amount of cover crop residue in direct-drill maize production while maintaining maize yields equivalent to a conventional system.

\section{MATERIALS AND METHODS}

A field trial was established on a Horotiu silt loam soil ( $\mathrm{pH}$ 6.8, TC 4.4\%), at the Northern Cropping
Research Site (NCRS) at Tamahere, near Hamilton in June 2016. The site had been used to grow maize the previous season. The maize grain was harvested in May. The ground was left fallow for about 3 weeks and the following four winter cover crops: gland clover (Trifolium glanduliferum) cv Prima; faba bean (Vicia faba) cv Ben; oats (Avena sativa) cv Milton; and ryegrass (Lolium multiflorum) cv Tama were drilled on 2 June 2016, in $6 \mathrm{~m}$ wide $\times$ $36 \mathrm{~m}$ long plots at rates of $6.6,300,100$ and $25 \mathrm{~kg} /$ ha respectively (Treatments 1-4). The plots were orientated east-west (columns) and replicated four times in a randomised block design. A winter fallow plot of the same dimensions (Treatment 5) was also included in the layout, Table 1. On 24 October 2016, winter cover crop dry matter (DM) cuts were taken. Dry matter was determined by placing a $1 \mathrm{~m}^{2}$ quadrat in a representative area within each plot and cutting to $10 \mathrm{~mm}$. The total fresh weight was recorded then a sub-sample $>200$ g was dried at $80^{\circ} \mathrm{C}$ for 48 hours to determine the DM content. The cover crops were pushed over by roller and sprayed with herbicide (Table 1). All herbicides were applied on the same day with a backpack sprayer powered by carbon dioxide at a water rate of 200 litres/ha (at $160 \mathrm{kPa}$ ), fitted with a boom holding four Teejet ${ }^{\circledR} 11003$ air inclusion (AI) nozzles, spaced at $75 \mathrm{~cm}$. Details of the herbicide treatments used are listed in Table 1.

Table 1 Main treatment cover crops, planted 2 June 2016, and crop-destruction herbicides, applied 24 October 2016.

\begin{tabular}{|c|c|c|c|}
\hline Treatment No. & Crop & Crop-destruction herbicide ${ }^{1}$ & Rate (g ai/ha) \\
\hline 1 & gland clover cv Prima & $\begin{array}{l}\text { glyphosate + tribenuron- } \\
\text { methyl }^{2}\end{array}$ & $1458+30$ \\
\hline 2 & faba bean cv Ben & paraquat & 800 \\
\hline 3 & oats cv Milton & glyphosate $^{2}$ & 1458 \\
\hline 4 & ryegrass cv Tama & glyphosate $^{2}$ & 1458 \\
\hline 5 & none (fallow) & glyphosate $^{2}$ & 1458 \\
\hline
\end{tabular}

${ }^{1}$ Trade names and formulations for the crop-destruction herbicides are glyphosate (Weedmaster ${ }^{\circledR}$ TS540, $540 \mathrm{~g} /$ litre glyphosate potassium and isopropylamine salts as a soluble concentrate), tribenuronmethyl (Granstar ${ }^{\circledR}, 750 \mathrm{~g} / \mathrm{kg}$ as a water dispersible granule), and paraquat (Gramoxone ${ }^{\circledR}, 200 \mathrm{~g} /$ litre paraquat dichloride salt as a soluble concentrate).

${ }^{2}$ Applied with Pulse Penetrant ${ }^{\circledR}$ 0.1\% v/v (contains greater than 800 g/litre organosilicone modified polydimethyl siloxane) 
Three days after applying the crop-destruction herbicide (27 October 2016), maize cv. Pioneer ${ }^{\circledR}$ 9911 was direct drilled aligning north-south (rows) at a seeding rate of 90,000 plants/ha, with YaraMila $^{\mathrm{TM}}$ starter fertiliser applied at $150 \mathrm{~kg} / \mathrm{ha}$. The direct drill unit was a 1750 John Deere planter equipped with front trash cleaners along with one spiked and one smooth closing wheel. Each of the 20 main plots were then divided into $5 \mathrm{sub}$ plots of $6 \times 6 \mathrm{~m}$, containing the remains of one cover crop and eight rows of maize, giving a total of 100 plots. Both main plots of cover crop and sub-plots of weed control were randomised. The pre- and post-emergence herbicide treatments used for controlling weeds in the maize crop are listed in Table 2. All herbicides were applied as for the crop-destruction herbicides. Metaldehyde (SlugOut ${ }^{\circledR}$ ) was applied broadcast at a rate of 216 $\mathrm{g}$ ai/ha three days after emergence to kill slugs and snails, and alpha-cypermethrin (Sheriff ${ }^{\circledR}$ 100) plus $70 \mathrm{~mL} / \mathrm{ha}$ Contact $^{\mathrm{TM}}$ Xcel at $20 \mathrm{~g}$ ai/ ha was used on 18 December 2016 to control armyworm. A stabilised urea fertiliser (SustaiN) was applied broadcast at a rate corresponding to $92 \mathrm{~kg}$ nitrogen per hectare, 18 days after maize emergence.

Visual assessments of residual ground coverage from the winter cover crop, weed ground cover and weed control relative to the vigour and height of the weeds in the untreated control plots were recorded weekly, until maize canopy closure 23 January 2017, 11 WAE. Maize emergence was assessed visually from $0-4$ weeks after planting and observational notes made on average leaf growth stage of maize plants in the cover crop treatments. Weed species in fallow untreated plots were identified and two counts were made at 4.6 and 6 WAE to obtain average weed density for the trial

Table 2 Sub-treatment herbicides, rate and timing of application for weed control in the spring-planted maize crop (27.10.2016).

\begin{tabular}{|c|c|c|c|c|c|}
\hline \multirow[b]{2}{*}{$\begin{array}{l}\text { Sub-trt. } \\
\text { No. }\end{array}$} & \multicolumn{2}{|c|}{ Pre-emergence } & \multicolumn{2}{|c|}{ Post-emergence } & \multirow{2}{*}{$\begin{array}{l}\text { Application } \\
\text { Time } \\
\left(\mathrm{WAE}^{2}\right)\end{array}$} \\
\hline & Herbicide $^{1}$ & $\begin{array}{l}\text { Rate } \\
\text { (g ai/ha) }\end{array}$ & Herbicide $^{1}$ & $\begin{array}{l}\text { Rate } \\
\text { (g ai/ha) }\end{array}$ & \\
\hline $\mathrm{i}$ & none & - & none & - & - \\
\hline ii & $\begin{array}{l}\text { acetochlor }+ \\
\text { saflufenacil }\end{array}$ & $2520+105$ & none & - & -1.3 \\
\hline iii & $\begin{array}{l}\text { acetochlor }+ \\
\text { saflufenacil }\end{array}$ & $2520+105$ & $\begin{array}{l}\text { topramezone }+ \\
\text { atrazine }^{3}\end{array}$ & $67.2+500$ & $-1.3 ; 5.7$ \\
\hline iv & none & - & $\begin{array}{l}\text { topramezone }+ \\
\text { atrazine }^{3}\end{array}$ & $67.2+500$ & 3.7 \\
\hline \multirow[t]{2}{*}{$\mathrm{v}$} & none & - & $\begin{array}{l}\text { mesotrione } \\
\text { atrazine }^{4}\end{array}$ & $96+500$ & 2.6 \\
\hline & & & nicosulfuron & 60 & 5.7 \\
\hline
\end{tabular}

${ }^{1}$ Trade names and formulations for the herbicides in Table 2: acetochlor (Roustabout ${ }^{\circledR}, 840 \mathrm{~g} /$ litre as an emulsifiable concentrate), saflufenacil (Sharpen ${ }^{\circledR}, 700 \mathrm{~g} / \mathrm{kg}$ as a water dispersible granule), topramezone (Arietta ${ }^{\circledR}, 336 \mathrm{~g} /$ litre as a suspension concentrate), mesotrione (Callisto ${ }^{\circledR}, 480 \mathrm{~g} /$ litre as a suspension concentrate), nicosulfuron (Astound ${ }^{\circledR}$ Ultra, $40 \mathrm{~g} /$ litre as an oil dispersion) and atrazine (Atraflow ${ }^{\mathrm{TM}}$, $500 \mathrm{~g} /$ litre as a suspension concentrate).

${ }^{2} \mathrm{WAE}=$ weeks after emergence, $\mathrm{a}-\mathrm{ve}$ sign means the herbicide was applied prior to maize crop emergence

${ }^{3}$ Applied with Hasten ${ }^{\mathrm{TM}} 0.5 \% \mathrm{v} / \mathrm{v}$ (704 g/litre methyl and ethyl esters of fatty acids from canola oil).

${ }^{4}$ Applied with Synoil ${ }^{\mathrm{TM}} 1 \% \mathrm{v} / \mathrm{v}$ (a propriety blend of refined paraffinic oil and polyol fatty acid esters). 
site. Average maize plant height was determined weekly, from 2 WAE to maize canopy closure, from four representative plants in the central four rows of the plot. Total leaf area of the 7 th emerged maize leaf at maturity was determined at 9 WAE with a bench-top LI-3100C leaf area meter. The average leaf area of the four sampled leaves is presented in Table 3. Slug and armyworm damage was also evaluated at this time by counting the number of centimetre squares on grid paper showing through the holes of each leaf. Maize plants were harvested for silage yield on 15 March 2017 (18.4 WAE), from a $1.5 \mathrm{~m}$ representative strip in the third central maize row of each plot. All plants within this strip were cut $10 \mathrm{~cm}$ above ground, their fresh weight recorded, then two plants mulched and a $>300$ g sub-sample dried in the oven at $80^{\circ} \mathrm{C}$ to determine the moisture content. Maize plants were counted within two representative $1.5 \mathrm{~m}$ strips from two central maize rows per plot in order to calculate plant populations and determine maize silage yield (t/ha DM).

All analyses were performed in $\mathrm{R}$ (version 3.3.2) and data were subjected to analysis of variance (ANOVA) to compare treatment means after data were normalised using a log or arcsine transformation as appropriate. Replicates and the row/col structure within reps was included as a blocking term in the ANOVA. All main effects and their interactions in the ANOVA were included. The treatment arithmetic means are presented in the tables. For weed ground cover data, a polynomial regression was fitted to predict mean cover scores and parametric bootstrapping to calculate confidence intervals $(\mathrm{P}<0.05)$. The Duncan's multiple range test was made to the P-values for the pairwise difference before assigning the letters at the $5 \%$ level of significance.

\section{RESULTS}

Winter cover crops emerged about 15 days after planting and established well, except for clover which was slow as it is known to be less cool tolerant (Bàrberi \& Mazzoncini 2001). Cover crop yields prior to maize planting were 1.2, 4.0, 6.7 and 4.6 DM t/ha for clover, faba bean, oats and ryegrass respectively.
Maize emergence appeared to be complete by 10 days after planting in the fallow, clover and faba bean winter treatments while oats and ryegrass delayed maize emergence further by up to 5 days.

Winter cover crop kill by herbicides was effective, although faba bean plots treated with paraquat still had some perennial clover, ryegrass and multi-crowned broadleaved dock surviving. Initial percent ground coverage of the cover crop residues after rolling and spraying were $35 \%$, $43 \%, 79 \%$ and $80 \%$ for the clover, faba bean, oats and ryegrass plots respectively (Figure 1). Fallow plots had 15\% cover from dead weeds. Rapid breakdown of clover residue was observed in the first week following maize planting with less than half $(11 \%)$ of its residue remaining (Figure 1). Breakdown thereafter was gradual with $6 \%$ remaining at maize canopy closure 11 WAE. Oats and ryegrass cover crops showed little degradation with the residue still providing a high level of physical cover over the soil (>70\%) at maize canopy closure. Faba bean residues provided intermediate cover and the fallow treatment showed rapid breakdown of winter herbaceous weeds following spraying (Figure 1).

Weed ingress, as evidenced by percent weed ground cover, was reduced by the presence of winter cover crop residues and by herbicides. Weeds in the fallow untreated plots (the control) were variable (with one replicate higher than others) but showed a steady increase reaching a mean of $51 \%$ ground cover at maize canopy closure (Figure 2). Faba beans reduced both weed establishment and growth (as evidenced by the slope of the curve) with final weed covers around $22 \%$ by canopy closure. Ryegrass, oats and clover severely reduced weed ingress to only about $8-10 \%$ cover (Figure 2 ). This equates to a reduction in weed cover compared to the winter fallow of $57 \%$ and $81-85 \%$ respectively.

Weed counts in fallow untreated plots indicated that this site had low to moderate weed density $\left(45-200 / \mathrm{m}^{2}\right)$ with the majority (86\%) being broadleaf species. Common annual weeds present included prostrate amaranth (Amaranthus deflexus), redroot (Amaranthus powellii), wireweed (Polygonum aviculare), 
Table 3 Leaf-7 area and insect/mollusc leaf damage (\%) at 9 WAE, average weed control (\%) at 11 WAE, and final plant populations, maize DM and silage yield at harvest (18.4 WAE). Results pooled according to herbicide treatment (sub-plots) and cover crop (main plots).

\begin{tabular}{|c|c|c|c|c|c|c|}
\hline \multicolumn{3}{|c|}{ 06.01.2017 (9 WAE) } & \multirow{2}{*}{$\begin{array}{c}23.01 .17 \\
(11 \mathrm{WAE}) \\
\\
\text { Weed } \\
\text { control } \\
(\%)\end{array}$} & \multicolumn{3}{|c|}{ 15.03.2017 (18.4 WAE) } \\
\hline $\begin{array}{l}\text { Herbicide } \\
\text { treatment }^{1}\end{array}$ & $\begin{array}{l}\text { Leaf-7 area } \\
\left(\mathrm{cm}^{2}\right)\end{array}$ & $\begin{array}{c}\text { Insect/ } \\
\text { mollusc } \\
\text { damage } \\
(\%)\end{array}$ & & $\begin{array}{l}\text { Population } \\
\text { (plants/ha) }\end{array}$ & $\begin{array}{l}\text { Maize DM } \\
(\%)\end{array}$ & $\begin{array}{c}\text { Silage yield } \\
(\mathrm{t} / \mathrm{ha} \mathrm{DM})\end{array}$ \\
\hline $\mathrm{i}$ & $287 \mathrm{ab}^{2}$ & $6.2 \mathrm{a}$ & $0 \mathrm{~d}$ & 86557 a & $34.0 \mathrm{a}$ & $22.2 \mathrm{a}$ \\
\hline ii & $273 \mathrm{~b}$ & $8.4 \mathrm{a}$ & $98 \mathrm{c}$ & 85246 a & $34.0 \mathrm{a}$ & $20.3 \mathrm{a}$ \\
\hline iii & $275 \mathrm{~b}$ & $8.2 \mathrm{a}$ & $100 \mathrm{a}$ & 85246 a & $34.1 \mathrm{a}$ & $20.0 \mathrm{a}$ \\
\hline iv & $304 \mathrm{a}$ & $6.4 \mathrm{a}$ & $99 \mathrm{~b}$ & 84808 a & $33.1 \mathrm{a}$ & $20.5 \mathrm{a}$ \\
\hline $\mathrm{v}$ & $312 \mathrm{a}$ & $5.5 \mathrm{a}$ & $100 \mathrm{ab}$ & $86776 \mathrm{a}$ & $33.9 \mathrm{a}$ & $23.1 \mathrm{a}$ \\
\hline \multicolumn{7}{|l|}{ Cover crop } \\
\hline Clover & $301 \mathrm{ab}$ & $1.7 \mathrm{~b}$ & 79 a & 88087 a & $35.1 \mathrm{a}$ & $24.7 \mathrm{a}$ \\
\hline Faba & $312 \mathrm{a}$ & $4.1 \mathrm{~b}$ & 79 a & $87650 \mathrm{a}$ & $33.6 \mathrm{ab}$ & $23.2 \mathrm{a}$ \\
\hline Fallow & 309 a & $1.2 \mathrm{~b}$ & 79 a & $86120 \mathrm{ab}$ & $34.0 \mathrm{ab}$ & $21.5 \mathrm{ab}$ \\
\hline Oats & $276 \mathrm{bc}$ & $14.5 \mathrm{a}$ & 79 a & $84153 \mathrm{ab}$ & $33.1 \mathrm{~b}$ & $19.2 \mathrm{bc}$ \\
\hline Rye & $252 \mathrm{c}$ & $13.1 \mathrm{a}$ & $79 \mathrm{a}$ & $82623 \mathrm{~b}$ & $33.1 \mathrm{~b}$ & $17.6 \mathrm{c}$ \\
\hline \multicolumn{7}{|l|}{ P-values } \\
\hline $\begin{array}{l}\text { Herbicide } \\
\text { treatment }\end{array}$ & $<0.001$ & 0.122 & $<0.001$ & $<0.001$ & 0.665 & 0.24 \\
\hline Cover crop & $<0.001$ & $<0.001$ & 0.373 & 0.556 & 0.05 & $<0.001$ \\
\hline $\begin{array}{l}\text { Herb:Crop } \\
\text { interaction }\end{array}$ & 0.37 & 0.0123 & 0.804 & 0.692 & 0.947 & 0.959 \\
\hline
\end{tabular}

${ }^{1}$ Refer to Table 2 .

${ }^{2}$ Treatments followed by the same letter are not significantly different from each other $(\mathrm{P}<0.05)$.

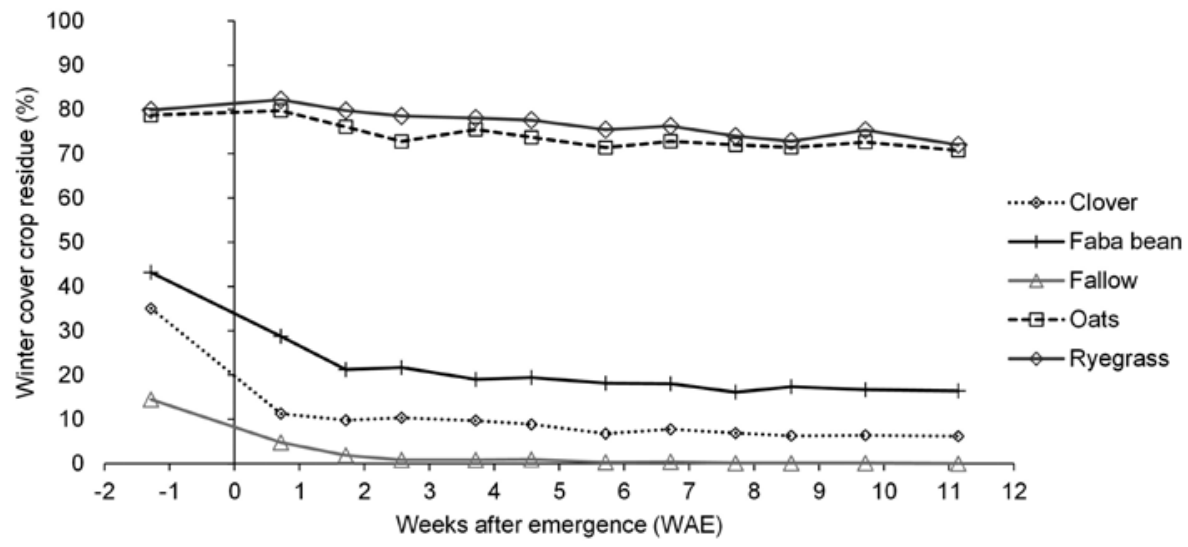

Figure 1 Weekly average winter cover crop residue ground covers (\%), from maize planting to maize canopy closure (11 WAE). 
Figure 2 Weekly weed ground cover scores (\%) for each cover crop from maize planting to canopy closure (11 WAE). Central line is the predicted mean and shaded area represents the $95 \%$ confidence interval (no overlap of the CI represents $\mathrm{P}<0.05)$.

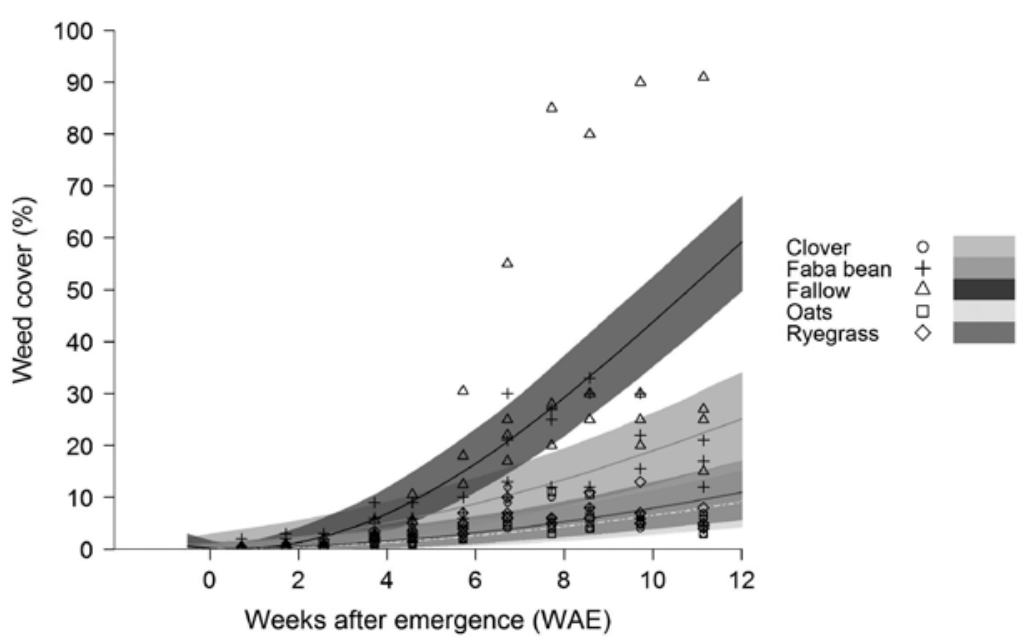

summer grass (Digitaria sanguinalis) and smooth witchgrass (Panicum dichotomiflorum).

All herbicide treatments provided excellent weed control throughout the season with $\geq 98 \%$ at maize canopy closure (Table 3 ).

Observations on number of emerged maize leaves and crop height showed that maize plants grown following the legume cover crops (clover and faba bean) generally had one or two more leaves and were slightly taller than those grown following oats and ryegrass, while maize grown in fallow land was intermediate (data not presented). Measurements of the 7 th emerged leaf showed that the leaf area was affected by cover crop as well as by herbicide treatments, but there was no evidence of an interaction between herbicide treatment and cover crop. The 7th leaf emerged about 4 WAE and was fully expanded 8-9 WAE. Maize plants within plots of oats and ryegrass residues had significantly $(\mathrm{P}<0.05)$ smaller leaf7 areas than those in faba bean residue or fallow plots (Table 3). Leaf-7 areas were also significantly smaller in maize treated with pre-emergence herbicides compared to post-emergence herbicides (Table 3). A significantly higher level of slug and armyworm damage was measured in the oats and ryegrass cover crop plots, but no difference in insect/mollusc damage was found under different herbicide treatments (Table 3).
Silage yield was influenced by cover crop but not by herbicide treatment. Maize yielded significantly $(\mathrm{P}<0.05)$ more $\mathrm{DM}$ when grown in cover crop residues of legumes compared to monocots (Table 3). Clover produced the highest DM (24.7 t/ha DM), while ryegrass the least (17.6 t/ha DM) with the fallow treatment being intermediate (Table 3). In the untreated fallow control plots, silage yield was unaffected by weeds and overall Treatment $i$ (average of all winter cover crop treatments without herbicides) produced the second highest silage yield of 22.2 t/ha DM (Table 3). Maize plant populations were generally higher in the legume cover crop plots and plants also showed a potential to stay green longer (Table 3 ).

\section{DISCUSSION}

Weed establishment between maize planting and canopy closure (11 WAE) was reduced by $57-85 \%$ by the cover crop residues compared to the winter fallow. The high level and prolonged physical cover by residues of oats and ryegrass appeared to be the main cause of weed reduction in these cover crops. This was not the case for clover, as initial breakdown was fast and remaining residue covers were only $6 \%$ at canopy closure, yet it provided weed suppression similar to the grasses. This could be as a result of allelopathic inhibition of some weed species as have been reported 
previously (Else \& Ilnicki 1988; Ross et al. 2001; Moraes et al. 2012). Maighany et al. (2007) reported a reduction in seed germination of redroot amaranth (Amaranthus retroflexus) in the presence of extracts of Persian (T. resupinatum) and Berseem clovers ( $T$. alexandrinum). Both prostrate and redroot amaranth were common in the current field trial so it is likely that Prima gland clover exhibited similar allelopathy and inhibited these species as well as others.

While the delay in maize emergence in the ryegrass and oats plots needs further investigation, the slight lag in leaf development and height could be related to soil nitrogen availability. Restovich et al. (2012) found that maize biomass and grain yields were higher in legume and control plots compared to those with grasses in a study using cover crops in a maizesoybean rotation. This result was related to soil nitrogen availability at planting and was inversely proportional to the $\mathrm{C}: \mathrm{N}$ ratio of the cover crop.

The significantly higher maize silage yields in the legume cover crops compared to the monocots, especially ryegrass, shows the added benefit of using legumes as part of the cover crop regime. There could be a possibility of combining both grass and legumes as a mix to utilise the added benefit of high ground covers of the grasses and the nitrogen input of the legume. A study by Heinrichs et al. (2001) tested six ratios of black oats and common vetch for nitrogen supply to maize and determined that $10 \%$ oats $/ 90 \%$ vetch was the most beneficial ratio, a C:N ratio of 18.6.

All herbicide regimes provided excellent weed control $(\geq 98 \%)$ throughout the growing season. However, even with the absence of herbicide in the fallow treatment, no adverse effect on maize silage yield was measured. The low weed pressure at this site and adequate summer rainfall this season meant that maize was not limited in the weedy untreated control plots. In the preliminary trial $(2015 / 16)$ where cover crops were unreplicated but the herbicide treatments were, maize grain yield was reduced in the untreated control by $3.0 \mathrm{t} / \mathrm{ha}$ compared to average yields including cover crops and herbicide treatments. In both years however, use of cover crops without any herbicide led to the production of similar grain or maize silage yields as standard herbicide regimes. This shows the potential of utilising cover crops to suppress weeds and minimise herbicide inputs. This needs to be further tested at sites with moderate to high weed densities to determine if cover crops suppress high weed infestations and can be used to reduce herbicide use, without compromising yield.

\section{ACKNOWLEDGEMENTS}

This research was funded by the Foundation for Arable Research. We thank the University of Waikato summer students Danni Hodges and Ashley Wade for maize leaf and yield harvests as well as Bridget Wise for silage harvest.

\section{REFERENCES}

Baker CJ, Collins RM, Choudhary MA 2003. Factors affecting the uptake of no-tillage in Australia, Asia and New Zealand. In Conservation Agriculture Springer Netherlands: 13-20.

Bàrberi P, Mazzoncini M 2001. Changes in weed community composition as influenced by cover crop and management system in continuous corn. Weed Science 49(4): 491-499.

Bezuidenhout SR, Reinhardt CF, Whitwell MI 2012. Cover crops of oats, stooling rye and three annual ryegrass cultivars influence maize and Cyperus esculentus growth. Weed Research 52(2): 153-160.

Densley RJ, Austin GM, Williams ID, Tsimba R, Edmeades GO 2006. Maize silage and winter crop options to maximise drymatter and energy for NZ dairy systems. Proceedings of the New Zealand Grassland Association 68: 193-197.

Else MJ, Ilnicki RD 1988. Allelopathic properties of subterranean clover. Proceedings of the 42nd Annual Meeting of the Northeastern Weed Science Society, p 65.

Fisk JW, Hesterman OB, Shrestha A, Kells JJ, Harwood RR, Squire JM, Sheaffer CC. 2001. Weed suppression by annual legume cover crops in no-tillage corn. Agronomy Journal 93(2): 319-325. 
Foundation for Arable Research 2005. Winter rotation crop options for maize grain producers. Arable update No. 34. https:// www.far.org.nz/resources/publications/ updates/maize/9 (accessed April 2017).

Galloway BA, Weston LA 1996. Influence of cover crop and herbicide treatment on weed control and yield in no-till sweet corn (Zea mays L.) and pumpkin (Cucurbita maxima Duch.). Weed Technology 10(2): 341-346.

Heinrichs R, Aita C, Amado TJC, Fancelli AL 2001. Vetch-oats mixtures: biomass $\mathrm{C} / \mathrm{N}$ ratio and corn production. Revista Brasileira de Ciência do Solo 25(2): 331-340.

Maighany F, Ghorbanli M, Khalghani J, Najafpour M 2007. Allelopathic potential of Trifolium resupinatum and $T$. alexandrium on seed germination of four weed species. Pakistan Journal of Biological Sciences 10(7): 1141-1143.

Millner JP, Roskruge NR 2013. The New Zealand arable industry. In: Dymond JR ed. Ecosystem services in New Zealand: conditions and trends. Manaaki Whenua Press, Christchurch, New Zealand. Pp. 102-114.

Moraes PVD, Panozzo LE, Vignolo GK, dos Santos LS, Brandolt RR 2012. Alellopathic effects of Trifolium vesiculosum on the growth of corn and weeds. Revista Agrarian 5(16): 99-105.
Pearson AJ, Wilson LR 2002. Impact of tillage system on sweet corn yield and some soil properties: year 2 of LandWISE Hawke's Bay. Agronomy New Zealand 32/33: 57-61.

Rahman A, James TK, Grbavac N, Mellsop J 1996. Spatial distribution of weed seedbank in maize cropping fields. Proceedings of the New Zealand Plant Protection Conference 49: 291-295.

Restovich SB, Andriulo AE, Portela SI 2012. Introduction of cover crops in a maizesoybean rotation of the Humid Pampas: Effect on nitrogen and water dynamics. Field Crops Research 128: 62-70.

Ross SM, King JR, Izaurralde RC, O'Donovan JT 2001. Weed suppression by seven clover species. Agronomy Journal 93(4): 820-827.

Triplett GB, Dick WA 2008. No-tillage crop production: a revolution in agriculture! Agronomy Journal 100 (Supplement_3): S-153-165.

Williams ID, Densley RJ, Edmeades GO, Kleinmans JJ, Mccarter SB 2010. Using maize silage to reduce the impact of dairy farm systems on water use and quality in New Zealand: A review. Proceedings of the 4th Australasian Dairy Science Symposium: Pp. 74-77.

Yenish JP, Worsham AD, York AC 1996. Cover crops for herbicide replacement in no-tillage corn (Zea mays). Weed Technology 10(4): 815-821. 